\title{
Health status of Marron, Cherax cainii (Austin, 2002) fed customized Probiotic Bacillus mycoides
}

\begin{abstract}
The present study examined the health status of marron Cherax cainii after feeding with a customised probiotic B. Mycoides supplemented diets at various feeding period by measuring intestinal bacterial population, hepatosomatic indices (Hiw), total haemocyte count (THC), bacteraemia and survival rate. During a 6 week feeding trial, the marron were fed at a rate of $1.5 \%$ of the total biomass per day with a commercial marron feed (basal diet) and B. mycoides (108 CFU/g of feed) supplemented diet. The first group of marron was solely fed on the basal diet while group two, three and four were fed with supplemented probiotic for one week, two weeks and four weeks, respectively before changing to the basal diet only.
\end{abstract}

The results suggested that intestinal bacterial population was higher in the probiotic fed groups compared to the basal diet fed marron. Among the probiotic fed groups, the highest intestinal bacterial population was observed in marron fed probiotic for four weeks. In addition, Hiw of the marron fed probiotic for four weeks was also higher than other feeding groups, whereas Hiw of basal diet fed marron was significantly lower compared to probiotic fed groups. No mortality was observed in any feeding group.

The longest probiotic feeding period (four weeks) resulted in a higher immune status as indicated by higher THC and lower bacteraemia. However, after shifting to a basal diet, a reduced intestinal bacterial population, Hiw and THC were observed in all groups, except bacteraemia. In conclusion, periodic or continues probiotic B. Mycoides feeding is required to maintain its high population levels and better health benefits in marron.
Volume 6 Issue 4 - 2017

\author{
Irfan Ambas,' Ravi Fotedar, ${ }^{2}$ Nicky Buller ${ }^{3}$ \\ 'Department of Fisheries, Hasanuddin University, Indonesia \\ ${ }^{2}$ Sustainable Aquatic Resources and Biotechnology, Department \\ of Environment and Agriculture, Curtin University, Australia \\ ${ }^{3}$ Animal Health Laboratories, Department of Agriculture and \\ Food Western Australia, Australia
}

Correspondence: Irfan Ambas, Department of Fisheries, Faculty of Marine Science and Fisheries, Hasanuddin University, Indonesia,Email irfanambas@yahoo.com

Received: October II, 2017 | Published: November 20, 2017

\section{Introduction}

Supplementation with probiotics is becoming an integral part of aquaculture practices to obtain high production and has shown enough evidence to play an important role in aquaculture, ${ }^{1,2}$ however probiotics often exert host specific and strain specific effects. ${ }^{3,4}$ Many factors significantly affect various desired outcomes including probiotic strains, form of the supplements, vector of administration, dosage and duration of the probiotic application. ${ }^{1,5}$

The use of probiotic bacteria is a strategy to overcome microbial problems, ${ }^{6}$ whereas modulation of the immune system is one of the most commonly purported benefits of the probiotic, ${ }^{1}$ thus the majority of probiotic application is for disease prevention. ${ }^{7}$ However, other than immunity modulation, numerous health benefits could be obtained with probiotic supplementation ${ }^{1}$ such as improved growth, ${ }^{8-14}$ improved enzyme activity ${ }^{15-20}$ and improved stress tolerance, ${ }^{21-23}$ whereas modulation and restoration of intestinal bacteria population $^{24-29}$ as a contribution to the overall health status of the host has been underestimated. ${ }^{30,31}$

Modulation and persistency of the probiotic in the gastrointestinal tract (GIT) in the host is commonly used as primary indicator of probiotic action. Gatesoupe ${ }^{32}$ surmised persistency of probiotics supplemented either daily or continuously in various fish species and shellfish is greatly varied. To improve persistency of probiotics, and for safety reasons, it is widely accepted that host origin (autochthonous) strains, especially mucus inhabitants ${ }^{33-36}$ with probiotic properties, offer improved safety, ability to colonise and multiply, and can remain predominant and persist in the same host $\mathrm{t}^{32,37,21,24,38}$ after changing to basal diets ${ }^{1}$ compared to commercial probiotic supplemented diets. ${ }^{39}$
Duration of supplementation significantly affects the establishment, persistence and subsequent induction of immune responses and desirable outcomes ${ }^{40,1}$ but the effect of feeding duration on probiotic efficacy remains scarcely investigated.$^{38}$ Probiotic studies have assessed potential applications for a periods as short as $24 \mathrm{~h}^{6}$ or 3 days ${ }^{41,42}$ up to 5 months ${ }^{43}$ but the effect of long-term efficacy is not available ${ }^{38}$ and the basis for choosing the probiotics supplementation period is often unclear. ${ }^{40}$

The present study evaluated the effect of feeding duration using a marron Cherax caiini host origin strain, Bacillus mycoides ${ }^{44,45}$ with previously demonstrated health benefits Ambas et al. ${ }^{46-48}$ by measuring intestinal bacterial population, hepatosomatic index (Hiw), total haemocyte count (THC), haemolymph bacteria (bacteraemia), glutathione peroxide (GPx) enzyme activity and survival rate.

\section{Materials and methods}

\section{Animals and experimental system}

Marron, Cherax caini $^{44}$ were supplied by Aquatic Resource Management Pty Ltd., Manjimup, Western Australia. Prior to commencement of the feeding trial, the juveniles were acclimated to the experimental conditions and basal diet for two weeks in the culture tanks. During the acclimation period, marron were fed the basal diet at a rate of $1.5 \%$ of the total biomass per tank once per day at 1700 hours.

Twelve cylindrical culture tanks $(80 \mathrm{~cm}$ diameter and $50 \mathrm{~cm}$ high and $250 \mathrm{~L}$ in capacity) were used in this study. The tanks were placed on three steel standing racks in a purpose-built laboratory designed for Curtin Aquatic Research Laboratory (CARL) Unit, Curtin University Australia. Each tank was filled with freshwater and supplied with 
constant aeration and provided with a submersible thermostat set to $24 \mathrm{oC}$ and a re-circulating biological filtration system (Fluval 205, Askoll, Italy) to maintain good water quality. Continuous running water in each tank was provided at a rate of approximately $3 \mathrm{~L} / \mathrm{min}$. The tanks contained sufficient marron shelters using PVC pipes of appropriate diameters.

After acclimation, marron of similar size were selected and distributed randomly into twelve culture tanks at 12 marron/tank. The marron were divided into four treatment groups as follows and each consisted of three replicates.

a. Marron fed solely on basal diet until termination of the trial (BD)

b. Marron fed with probiotic diet for one week then changed to basal diet (Pro-1w).

c. Marron fed with probiotic diet for two weeks then changed to basal diet (pro-2w).

d. Marron fed with probiotic diet for four weeks then changed to basal diet (pro-4w).

e. This basal diet was fed to marron up to one week after probiotics feeding ceased.

\section{Feed and test diets}

The commercial marron diet supplied by specialty feeds, Glen Forrest Western Australia was used as control or basal diet. The proximate composition of the basal diet was: $26 \%$ crude protein, $9 \%$ crude fat and $5 \%$ crude ash.

The experimental diets (basal and probiotic supplemented diets) were prepared prior to the feeding trial. The probiotic supplemented diet using Bacillus mycoides, a host-origin strain isolated from mature healthy marron with probiotic properties ${ }^{44}$ was prepared on a weekly basis. Identification of the probiotic isolate was performed by the Bacteriology Laboratory, Animal Health Laboratories, Department of Agriculture and Food, Western Australia, using a matrix-assisted laser desorption ionization time-of-flight (MALDI-TOF) mass spectrometer (Bruker Bioscience Corporation), Vitek Compact II (Biomerieux) and conventional biochemical methods according to standard procedures and identification methods. ${ }^{45}$ The strain was suspended into $1 \mathrm{~mL}$ aliquots of GLL (Glycerol Lab Lemco broth) and stored at $-80^{\circ} \mathrm{C}$.

The probiotic diet was prepared according to Hai \& Fotedar. ${ }^{10}$ In brief, a pure culture of B. mycoideswas grown on blood agar (BA) plates for $24 \mathrm{~h}$ at $25^{\circ} \mathrm{C}$. Colonies in logarithmic phase of growth were emulsified in sterilised distilled water and serially diluted. The optical reading of each serial dilution was recorded, and a viable count performed to obtain a standard curve for inoculum density. From the standard curve, the amount of the diluted probiotic was calculated to achieve the desirable supplementation density of 108colony forming unit (CFU) per gram of feed; a density used in most Bacillus species studies. The pellets were air dried, packed and stored at $4{ }^{\circ} \mathrm{C}$ until used.

\section{Data collection}

The immune parameters including total haemocyte count, total bacterial count in haemolymph (bacteraemia), Hiw and survival rate were performed at the termination of each probiotic feeding period, except the intestinal bacteria population which was measured one week after changing to the basal diet.

\section{Intestinal bacteria population}

Intestinal bacterial density as indicator of marron heath was determined following the established protocol..$^{10}$ Five of equal size marron from each treatment group were selected and rinsed in distilled water prior to intestinal bacterial count. The shells were cleaned with $70 \%$ alcohol then rinsed in distilled water to remove the external bacteria. Following dissection, the intestine from individual marron was removed and weighed, then homogenised using a sterilised pestle and mortar. Serial dilutions of the homogenates in sterilised normal saline were performed and lawn inoculated to blood agar (BA) plates prior to incubation for $24 \mathrm{~h}$ at $25 \mathrm{oC}$. The total colony forming units (CFU) for each plate and $\mathrm{CFU} / \mathrm{mL}$ were calculated on the basis of a total volume of $0.05 \mathrm{~mL} /$ plate from each serial dilution. ${ }^{45}$ Along with intestinal bacterial density, persistency of supplemented probiotic, $B$. mycoides was also observed up to two weeks post probiotic supplementation or basal diets.

\section{Total haemocyte count (THC)}

Measurement of THC followed the established methods described by Jussila et al. (1997). ${ }^{46} \mathrm{In}$ brief, $0.5 \mathrm{~mL}$ of haemolymph withdrawn from the second last ventral segment of marron placed into a haemocytometer (The Neaubauer Enhanced Line, Munich, Germany) counting chamber and immediately viewed under 100fold magnification of camera-equipped microscope and images were taken for later THC counts. Cells were counted in both grids, and the mean was used as the haemocyte count. For each treatment group, the procedure was repeated using five different animals. The total haemocyte count was calculated as $\mathrm{THC}=($ cells counted $\mathrm{x}$ dilution factor x 1000)/volume of grid (0.1 mm3).

\section{Glutathione peroxidase (GPx) enzyme activity}

The preparation and determination of the GPx activity in marron tissue followed established methods ${ }^{47}$ Marron tissue was diluted with physiological saline at a ratio of $1: 1$ and stored at $40 \mathrm{C}$ until used. To calculate GPx activity, $0.2 \mathrm{~mL}$ tissue homogenates (homogenized in $0.4 \mathrm{M}$ sodium phosphate buffer, $\mathrm{pH} 7.0$ ), $0.1 \mathrm{~mL} 10 \mathrm{mM}$ sodium azide, $0.2 \mathrm{~mL} 0.2 \mathrm{mM}$ reduced glutathione, and $0.1 \mathrm{~mL} 0.2 \mathrm{mM}$ hydrogen peroxide were mixed., The mixtures were incubated for 10 min at $37^{\circ} \mathrm{C}$ after which $0.4 \mathrm{~mL}$ of $10 \%$ trichloroacetic acid (TCA) was added. The mixtures were then centrifuged at $3200 \mathrm{rpm}$ for $20 \mathrm{~min}$. The supernatant was assayed for glutathione content using Ellman's reagent (9.8 mg 5,5'-dithiobis-[2-nitrobenzoic acid] [DTNB] in $100 \mathrm{~mL} 0.1 \%$ sodium citrate). The GPx activity was expressed as micrograms of GSH consumed per minute per milligram of protein.

\section{Hepatosomatic indices(Hiw)}

The wet hepatosomatic indices (Hiw) of marron fed probiotic supplemented diets at various periods were calculated as per established equations. ${ }^{48,49}$ In brief, hepatopancreas of marron from each treatment group were removed, placed in foil and weighed. The wet hepatosomatic indices (Hiw), was calculated as follows;

Hiw $=$ Wwh $\times 100 \mathrm{Wt}^{-1}$

Where;

Hiw $=$ Wet hepatosomatic indices $(\%)$

Wwh $=$ Weight of hepatopancreas (wet)

$\mathrm{Wt}=$ Total weight of marron $(\mathrm{g})$

\section{Survival rate (\%)}

Survival rate of marron was calculated at the termination of the experimental period by counting the number of marron in each tank and calculated using the following formula; $\mathrm{SR}(\%)=(\mathrm{Nt} / \mathrm{No}) \times 100$ 
where SR is the survival rate (\%); $\mathrm{Nt}$ is the number of marron at time $t$ and No is the number of marron at the commencement (o), respectively.

\section{Water quality}

To maintain optimum water quality conditions for marron, water exchange at a rate of $10-15 \%$ of the total water volume was performed once a week, after siphoning out the faeces and uneaten feeds. Several water quality parameters were monitored weekly including total ammonia (ppm) measured using Calorimeter PR 1890, USA; temperature $(\mathrm{oC})$ and $\mathrm{pH}$ using a digital $\mathrm{pH} / \mathrm{mV} / \mathrm{C}$ meter, Cyberscan pH300, Eutech instruments Singapore; and dissolved oxygen (ppm) using a digital DO meter SM600, Milwaukee, Romania.

\section{Data analysis}

The data were analysed using SPSS statistical package version 23.0 for Windows and Microsoft Excel 2010. Significant differences among treatment means were determined using one way analysis of variance (ANOVA). All significant tests were performed at $\mathrm{P}<0.05$ level and results were presented as means $\pm \mathrm{SE}$ (standard error).

\section{Results}

\section{Intestinal bacterial population}

Overall, the intestinal bacterial population increased in marron fed both the basal diet and the probiotic over all feeding times. However, intestinal bacterial population of probiotic fed marron was significantly higher $(\mathrm{P}<0.05)$ than the basal diet fed marron. A significant increase of bacterial population was observed in probiotic fed marron from week-1 to week-2, but increased at slow rate in basal diet fed marron. Intestinal bacterial population among the probiotic fed marron was observed significantly higher $(\mathrm{P}<0.05)$ in marron fed probiotic for four weeks than the other time periods and the basal diet fed marron.

Data in the same row having the same superscript letter $(a ; b)$ indicate a similar mean which is not significantly different at $\alpha$ level of 0.05.Data in the same column within an index having different subscript letters $(1,2)$ are significantly different at $\alpha$ level of 0.05 .

\section{Total haemocyte count (THC)}

During the feeding trials the highest THC was observed in marron fed probiotic supplemented diet for four weeks compared to other diets. In general, the THC of probiotic fed marron (one to four weeks) was higher than THC of basal diet fed marron.

\section{Glutathione peroxidase (GPx)}

Glutathione peroxidase (GPx) enzyme activity of marron fed a basal diet or a probiotic supplemented diet for one to four weeks is presented in Figure 1- 3. The results show that the highest GPx enzyme activity (83.27 ug GSH consumed min $^{-1}$ mg protein $^{-1}$ ) was observed in probiotic application and the basal diet fed marron. One week probiotic application significantly $(\mathrm{P}<0.05)$ improved the GPx enzyme activity of marron compared to GPx of the basal diet fed marron, however the longer probiotic feeding up to four weeks the higher GPx enzyme activity of the marron.

\section{Hepatosomatic indices $\left(\mathbf{H}_{\mathrm{iw}}\right)$}

Hepatopancreas has been used as indicator of health and nutritional status of crustacean including marron. ${ }^{50}$ The wet hepatosomatic indices $\left(\mathrm{H}_{\mathrm{iw}}\right)$ was significantly higher $(\mathrm{P}<0.05)$ in marron fed probiotic diets for four weeks compared to other feeding periods. The Hiw of two weeks probiotic fed marron is not significantly different from 1 week probiotic fed marron, whereas the Hiw of basal diet fed marron was not significantly $(\mathrm{P}>0.05)$ different with the Hiw of 1 week probiotic fed marron.

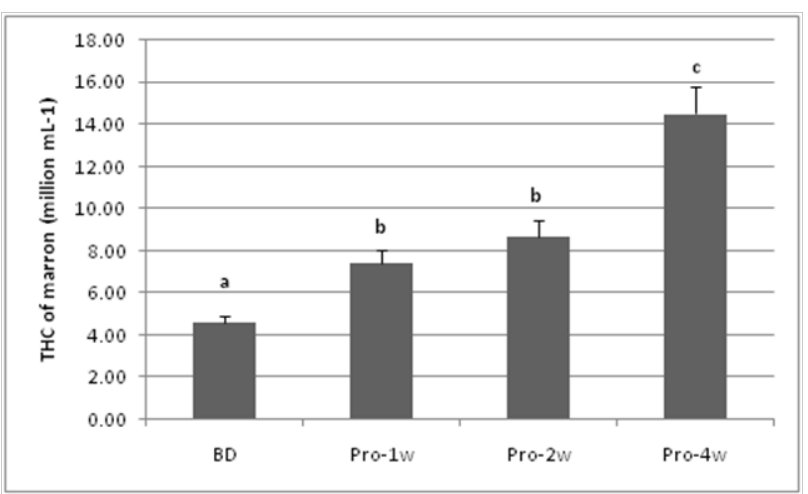

Figure I THC (million/mL) of marron fed basal and probiotic diets at various period (week).

Different letters over bars indicates significantly different at 0.05 .

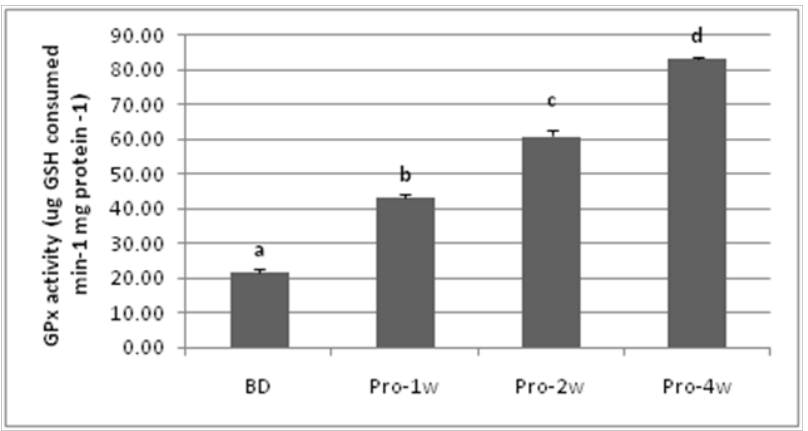

Figure 2 GPx enzyme activity of marron tissue muscle fed basal and probiotic diets at various duration (week). Different letters over bars indicates significantly different at 0.05 .

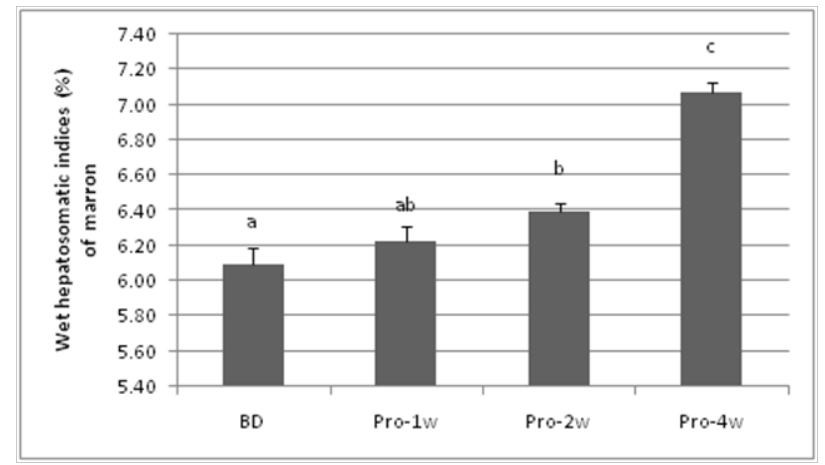

Figure 3 Hepatosomatic indices $\left(\mathrm{Hi}^{\mathrm{w}}\right)$ of marron fed basal and probiotic diets at various duration (week). Different letters over bars indicates significantly different at 0.05 .

\section{Survival rate (\%).}

No mortalitywas observed in any treatment group during the 6 weeks of feeding.Both probiotic and basal diet feeds nutritionally met the lowest nutrient requirement for marron to survive (Table 1).

\section{Water quality}

The selected parameters namely dissolved oxygen (ppm), 
temperature $(\mathbf{o C}), \mathrm{pH}$ and ammonia $(\mathrm{ppm})$ are presented in the Table 2 . The results revealed that the water quality was within the range for optimum growth of marron ${ }^{51}$ as each tank was equipped with biofiltration and regular water exchanges were performed. There was no significant difference in any of the water quality parameters among the treatments.

Table I Intestinal bacterial population (million CFU/g of gut) of marron fed probiotic supplemented diets for different duration

\begin{tabular}{lllll}
\hline Diets & 0 Week & I Week & 2 Weeks & 4 Weeks \\
\hline Basal diet & $42 I \pm 35.5^{1, \mathrm{a}}$ & $530.2 \pm 24.6^{1, \mathrm{~b}}$ & $585 \pm 20.5^{1, \mathrm{bc}}$ & $615 \pm 35.5^{1, \mathrm{c}}$ \\
Probiotics & $42 I \pm 35.5^{1, \mathrm{a}}$ & $637.5 \pm 26.7^{2, \mathrm{~b}}$ & $980 \pm 54.5^{2, \mathrm{c}}$ & $1085 \pm 51.5^{2, \mathrm{c}}$ \\
\hline
\end{tabular}

Table 2 Water quality parameters in experimental tanks during feeding trial

\begin{tabular}{lllll}
\hline Parameters & Basal Diet & I Week & 2 Weeks & 4 Weeks \\
\hline Ammonia (Ppm) & $0.041 \pm 0.02^{\mathrm{a}}$ & $0.035 \pm 0.03^{\mathrm{a}}$ & $0.038 \pm 0.02^{\mathrm{a}}$ & $0.045 \pm 0.05^{\mathrm{a}}$ \\
$\mathrm{pH}$ & $7.55 \pm 0.08^{\mathrm{a}}$ & $7.65 \pm 0.05^{\mathrm{a}}$ & $7.78 \pm 0.05^{\mathrm{a}}$ & $7.65 \pm 0.03^{\mathrm{a}}$ \\
Temperature (oC) & $24.27 \pm 0.55^{\mathrm{a}}$ & $24.47 \pm 0.65^{\mathrm{a}}$ & $23.95 \pm 0.35^{\mathrm{a}}$ & $24.35 \pm 0.33^{\mathrm{a}}$ \\
Dissolved oxygen (Ppm) & $6.25 \pm .025^{\mathrm{a}}$ & $6.55 \pm 0.15^{\mathrm{a}}$ & $6.35 \pm 0.45^{\mathrm{a}}$ & $6.28 \pm 0.25^{\mathrm{a}}$ \\
\hline
\end{tabular}

Data in the same row having the same superscript letter $(a ; b)$ indicate a similar mean which is not significantly different at $\alpha$ level of 0.05 .

\section{Discussion}

The study of the effect of feeding duration on probiotic efficacy remains scarcely investigated. ${ }^{40,38}$ Short term supplementation with probiotics has proved beneficial, ${ }^{38}$ whereas long-term administration may reduce the efficacy and induce immunosuppression in fish; however the side effects of a long-term administration, especially with probiotics have not been well-studied. ${ }^{53}$

The intestinal bacterial population of marron increased significantly one week after probiotic feeding commenced for up to four weeks, indicating that $B$. mycoides was able to stimulate the gut microbial population of marron. Our previous work also demonstrated that $B$. mycoides significantly improved the intestinal bacterial population of marron compared to the commercial probiotic strains ${ }^{46}$ Modulation of GIT bacterial population and restoration of a normal microbiota constitutes the key components to maintain good health throughout the development stages of the animals ${ }^{57}$ and this a stable commensal microbiota is part of the natural resistance to infections..$^{25}$

Supplementation of probiotics, particularly with host origin strains, restores and improves microbial population (diversity and density), as the added probiotic provides a favourable environment for the indigenous intestinal bacteria, whereas potential pathogens are suppressed..$^{58,27,28,69,27}$ Reduction of either population or diversity will reduce protection provided by the indigenous microbiota ${ }^{29}$ and diminish other beneficial contributions including enzymes, amino acids, and vitamins. ${ }^{60-62,20}$

Persistency within GIT is often used as preliminary indicator for the induction of probiotic efficacy ${ }^{32,34}$ as the probiotic benefits are presumably lost after the probiotic disappear from the host. ${ }^{38}$ This argument is supported by several findings where beneficial effects rely on viable cells compared to non-viable cells ${ }^{63,64}$ as viability is an important property for adherence and colonization of the intestinal tract of the host. ${ }^{1}$ In the present study, persistency of $B$. mycoides in marron GIT was observed for up two weeks after changing to a basal diet indicated that this host origin strain may persist in the GIT from the animal they were isolated.

The reduction or disappearance from the GIT after changing to a basal diet was observed in several studies using host origin probiotics.
Balcazar et al. ${ }^{24}$ evaluated fish origin lactic acid bacteria (LAB) groups Lactococcus lactis, Lactobacillus sakei and Leuconostoc mesenteroides fed at $\times 10^{6} \mathrm{cfu} / \mathrm{g}$ of feed to brown trout Salmo trutta for 2 weeks and detected high numbers in the intestines during the probiotic feeding period but then decreased gradually, although the bacteria could be detected at $1 \times 10^{2} \mathrm{cfu} / \mathrm{g}$ two weeks after shifting to a basal diet. In abalone Haliotis gigantea, hostderived Pediococcus sp. was able to colonized the gut for 12 days after shifting to a commercial basal diet. ${ }^{65}$ Higher gut colonization and longer retention time of host origin probiotic was observed in Nile tilapia Oreochromis niloticus, whereas the commercial probiotic disappeared rapidly from the gut. ${ }^{39}$ In trout Oncorhynchus mykiss, a two weeks probiotic Lactobacillus rhamnosus feeding trial resulted in a high number during the probiotic feeding but disappeared from the intestine, skin mucus and water within one week after changing to a probiotic-free diet ${ }^{66}$ whereas a $24^{\text {th }}$ probiotic treatment period in Atlantic cod Gadus morhua decreased to initial levels within 4 days. ${ }^{6}$

In Atlantic cod Gadus morhua L, ${ }^{6}$ proposed a strategy for introducing probiotic bacteria to the fish larvae either as a continuous supply or as repeated additions every 3-4 days. This short-term-cyclic feeding could provide direct benefits of short-term application during probiotic and probiotic-free feeding periods, but this could also help to avoid over-stimulating the immune response whilst maintaining a level of protection. ${ }^{38}$

On the other hand, a long dietary probiotic application is advantageous to the host in many aspects, ${ }^{1}$ as the continual application may lead to high levels of colonisation and modulate GIT microbial populations. ${ }^{38,67}$ Our previous work also confirmed that marron fed probiotic up to 70 days resulted in an improved THC at day $35^{\text {th }}$ and at day $70^{\text {th }}$ with no mortalitis after pathogen (Vibrio mimicus) challenge test. ${ }^{47}$ In crayfish, haemocytes are involved in many immune functions such as phagocytosis, encapsulation, storage and release of the proPO system, and cytotoxicity ${ }^{68}$ whereas marron haemocytes also contain oxidative enzymes such as glutathione-S-transferase (GST) and glutathione peroxidase (GPx). ${ }^{69}$ However, the THC of shrimp $P$. vannamei fed Vibrio spp. as probiotic candidates for 4 and 8 weeks showed no differences. ${ }^{64}$ Many studies demonstrated that 2 weeks probiotics feeding results in higher immunity of the animals than the other feeding periods, ${ }^{1}$ but the longevity of the health effect of probiotics is often uncertain. ${ }^{2}$

Hepatopancreas is the main energy reserve in crustaceans and a source of various enzymes which used as an indicator of nutritional status in marron..$^{50,53}$ In this study, the highest Hiw was observed in 4 week probiotic fed marron, which indicates a better nutritional status compared to other treatments. Our previous work also suggested that $B$. mycoides improved the Hiw of marron especially at day $35 .{ }^{47}$ The hepatopancreas is also as a source of enzymes, ${ }^{70}$ thus different size of Hiw as a result of probiotic feeding periods also indicates different enzyme activities. In Atlantic cod G. morhua L, improvement in the intestinal enzyme activity was observed after 40 days probiotic feeding compared to 20 days of feeding. ${ }^{71}$ Meanwhile, Gómez \& Shen ${ }^{17}$ proposed that a prolonged (45 days) probiotic feeding period using the optimum percentage of Bacillus spp. could enhance the digestive enzyme activity, whereas short feeding periods (ontogenetic stages) using $B$. coagulans SC8168 on shrimp P. vannamei larvae significantly increased some digestive enzyme activities. ${ }^{18}$

In conclusion, the present study suggested that supplementation of host origin probiotic $B$. mycoides is required longer to maintain a high population and predominant levels and for improved health benefits to the host. Further study is required to determine the period 
till the beneficial effects of dietary supplementation lasts in GIT after the probiotic supplementation is terminated. It is also imperative to know whether the reduction in initial levels of supplemented probiotic strain is sufficient to provide the desired beneficial outcomes and the level of protection to the host.

\section{Acknowledgments}

None.

\section{Conflicts of interest}

None

\section{References}

1. Nayak SK. Probiotics and immunity: A fish perspective. Fish shellfish immunology. 2010;29(1):2-14.

2. Newaj-Fyzul A, Al-Harbi AH, Austin B. Review: Developments in the use of probiotics for disease control in aquaculture. Aquaculture. 2014;431:1-11.

3. Hai, Buller N, Fotedar R. Effect of Customized Probiotics on the Physiological and Immunological Responses of Juvenile Western King Prawns (Penaeus latisulcatus Kishinouye, 1896) Challenged with Vibrio harveyi. Journal of Applied Aquaculture. 2010;22(4):321-336.

4. Hai. The use of probiotics in aquaculture. Journal of Applied Microbiology. 2015;119(4):917-935.

5. Mohapatra S, Chakraborty T, Kumar V, et al. Aquaculture and stress management: a review of probiotic intervention. J Anim Physiol Anim Nutr. 2013;97(3):405-430.

6. Skjermo J, Bakke I, Dahle SW, et al. Probiotic strains introduced through live feed and rearing water have low colonizing success in developing Atlantic cod larvae aquacult. 2015;438:17-23.

7. Kesarcodi-Watson A, Kaspar H, Lategan MJ, et al. Performance of single and multi-strain probiotics during hatchery production of Greenshell ${ }^{\mathrm{TM}}$ mussel larvae, Perna canaliculus. Aquaculture. 2012;354-355:56-63.

8. Gildberg A, Mikkelsen H, Sandaker E, et al. Probiotic effect of lactic acid bacteria in the feed on growth and survival of fry of Atlantic cod (Gadus morhua). Hydrobiologia. 1997;352:279-285.

9. Rengpipat S, Phianphak W, Piyatiratitivorakul S, et al. Effects of a probiotic bacterium on black tiger shrimp Penaeus monodon survival and growth. Aquaculture. 1998;167(3-4):301-313.

10. Hai NV, Buller N, Fotedar R. Effects of probiotics (Pseudomonas synxantha and Pseudomonas aeruginosa) on the growth, survival and immune parameters of juvenile western king prawns (Penaeus latisulcatus Kishinouye, 1896). Aquaculture research. 2009a;40(5):590602.

11. Merrifield, Bradley G, Remi TM Baker, et al. Probiotic applications for rainbow trout (Oncorhynchus mykiss Walbaum) I. Effects on growth performance, feed utilization, intestinal microbiota and related health criteria post antibiotic treatment. Aquaculture Nutrition. 2010a ;16(5):496-503.

12. Rahiman, Jesmi Y, Thomas AP, et al. Probiotic effect of Bacillus NL110 and Vibrio NE17 on the survival, growth performance and immune response of Macrobrachium rosenbergii (de Man). Aquaculture research. 2010;41(9):120-134.

13. Sun YZ, Yang HL, Ma RL, et al. Probiotic applications of two dominant gut Bacillus strains with antagonistic activity improved the growth performance and immune responses of grouper Epinephelus coioides. Fish \& shellfish immunology. 2010;29(5):803-809.

14. Giannenas I, Karamaligas I, Margaroni M, et al. Effect of dietary incorporation of a multi-strain probiotic on growth performance and health status in rainbow trout (Oncorhynchus mykiss). Fish Physiol Biochem. 2015;41(1):119-128.
15. Ziaei-Nejad S, Rezaei MH, Takami GA, et al. The effect of Bacillus spp. bacteria used as probiotics on digestive enzyme activity, survival and growth in the Indian white shrimp Fenneropenaeus indicus. Aquaculture. 2006;252(2-4):516-524.

16. Wang YB. Effect of probiotics on growth performance and digestive enzyme activity of the shrimp Penaeus vannamei. Aquaculture. 2007;269(1-4):259-264.

17. Gómez RGD, Shen MA. Influence of probiotics on the growth and digestive enzyme activity of white Pacific shrimp (Litopenaeus vannamei). Journal of Ocean University of China. 2008;7(2):215-218.

18. Zhou XX, Wang Y, Li W. Effect of probiotic on larvae shrimp (Penaeus vannamei) based on water quality, survival rate and digestive enzyme activities. Aquaculture. 2009;287(3-4):349-353.

19. Ye JD, Wang K, Li FD, et al. Single or combined effects of fructoand mannan oligosaccharide supplements and Bacillus clausii on the growth, feed utilization, body composition, digestive enzyme activity, innate immune response and lipid metabolism of the Japanese flounder Paralichthys olivaceus. Aquac Nutr. 2011;17(4):902-911.

20. Ray AK, Ghosh K, Ringo E. Enzyme-producing bacteria isolated from fish gut: a review. Aquaculture Nutrition. 2012;18(5):465-492.

21. Rollo A, Sulpizio R, Nardy M, et al. Live microbial feed supplement in aquaculture for improvement of stress tolerance. Fish Physiol Biochem. 2006;32(2):167-177.

22. Liu, Chiu CH, Shiu YL, et al. Effects of the probiotic, Bacillus subtilis E20, on the survival, development, stress tolerance, and immune status of white shrimp, Litopenaeus vannamei larvae. Fish shellfish immunol. 2010;28(5-6):837-844.

23. Hoseinifar SH, Roosta Z, Hajimoradloo A, et al. The effects of Lactobacillus acidophilus as feed supplement on skin mucosal immune parameters, intestinal microbiota, stress resistance and growth performance of black swordtail (Xiphophorus helleri). Fish \& Shellfish Immunology. 2015;42(2):533-538.

24. Balca'zar JL, Blas Id, Ruiz-Zarzuela I, et al. Changes in intestinal microbiota and humoral immune response following probiotic administration in brown trout (Salmo trutta). Br J Nutr. 2007;97(3):5225277.

25. Denev S, Staykov Y, Moutafchieva R, et al. Microbial ecology of the gastrointestinal tract of fish and the potential application of probiotics and prebiotics in finfish aquaculture. Int Aquat Res. 2009;1:1-29.

26. Gaggì F, Mattarelli P, Biavati B. Review Probiotics and prebiotics in animal feeding for safe food production. International Journal of Food Microbiology. 2010;141:S15-S28.

27. Dimitroglou A, Merrifield DL, Carnevali O, et al. Microbial manipulations to improve fish health and production - A Mediterranean perspective. Fish \& Shellfish Immunology. 2011;30(1):1-16.

28. Tapia-Paniagua ST, Reyes-Becerril M, Ascencio-Valle F, et al. Modulation of the Intestinal Microbiota and Immune System of Farmed Sparus aurata by the Administration of the Yeast Debaryomyces hansenii L2 in Conjunction with Inulin. J Aquac Res Development. 2011.

29. Ige BA. Probiotics use in intensive fish farming. International Journal of Agricultural Research and Natural Resources. 2013;7(2):1-11.

30. Gómez RGD, Balcázar JL, Shen MA. Probiotics as Control Agents in Aquaculture. Journal of Ocean University of China. 2007;6:76-79.

31. Ghanbari M, Kneifel W, Domig KJ. A new view of the fish gut microbiome: Advances from next-generation sequencing. Aquaculture. 2015;448(1):464-475.

32. Gatesoupe FJ. The use of probiotics in aquaculture. Aquaculture. 1999;180(1-2):147-165. 
33. Jöborn A, Olsson JC, Westerdahl A, et al. Colonisation in the fish intestinal tract and production of inhibitory substances in intestinal mucus and faecal extracts by Carnobacterium sp. K1. Journal of fish diseases. 1997;20(5):383-392.

34. Vine N, Leukes WD, Kaiser H, et al. Competition for attachment of aquaculture candidate probiotic and pathogenic bacteria on fish intestinal mucus. Journal of Fish Diseases. 2004;27(6):319-326.

35. Kim DH, Brunt J, Austin B. Microbial diversity of intestinal contents and mucus in rainbow trout (Oncorhynchus mykiss). J Appl Microbiol. 2007;102(6):1654-1664.

36. Merrifield, Harper G, Baker RTM, et al. Possible influence of probiotic adhesion to intestinal mucosa on the activity and morphology of rainbow trout (Oncorhynchus mykiss) enterocytes. Aquacult Res. 2010c ;41(8):1268-1272.

37. Verschuere L, Rombaut G, Sorgeloos P, et al. Probiotic Bacteria as Biological Control Agents in Aquaculture. Microbiology and Molecular Biology Reviews. 2000;64(4):655-671.

38. Merrifield, Dimitroglou A, Foey A, et al. The current status and future focus of probiotic and prebiotic applications for salmonids. Aquaculture. $2010 \mathrm{~b} ; 302(1-2): 1-18$.

39. Ridha MT, Azad IS. Effect of autochthonous and commercial probiotic bacteria on growth, persistence, immunity and disease resistance in juvenile and adult Nile tilapia Oreochromis niloticus. Aquaculture research. 2015;47(9):2757-2767.

40. Sharifuzzaman SM, Austin B. Influence of probiotic feeding duration on disease resistance and immune parameters in rainbow trout. Fish \&Shellfish Immunology. 2009;27(3):440-445.

41. Sakai M, Yoshida T, Astuta S, et al. Enhancement of resistance to vibriosis in rainbow trout, Oncorhynchus mykiss (Walbaum) by oral administration of Clostridium butyricum bacteria. Journal of fish diseases. 1995;18(2):187-190.

42. Gram L, Melchiorsen J, Spangaard B, et al. Inhibition of Vibrio anguillarum by Pseudomonas fluorescens AH2, a possible probiotic treatment of fish. 1999;65(3):969-973.

43. Aubin J, Gatesoupe FJ, Labbe L, et al. Trial of probiotics to prevent the vertebral column compression syndrome in rainbow trout ( Oncorhynchus mykiss ) Walbaum. Aquac Res. 2005;36(8):758-767.

44. Ambas I, Buller N, Fotedar R. Isolation and screening of probiotic candidates from marron, Cherax cainii (Austin, 2002) gastrointestinal tract (GIT) and commercial probiotic products for the use in marron culture. Journal of Fish Diseases. 2015a;38(5):467-476.

45. Buller NB. Bacteria from Fish and Other Aquatic Animals: A Practical Identification Manual. CABI Publishing, Oxford shire, UK. 2004.

46. Jussila J. Carapace mineralisation and hepatopancreatic indices in natural and cultured population of marron (Cherax tenuimanus) in Western Australia. Marine and Freshwater Research. 1997;48(1):67-72.

47. Rotruck JT, Pope AL, Ganther HE, et al. Selenium: biochemical role as a component of glutathione peroxidase. Science. 1973;179(4073):585590 .

48. Jussila J, Jago J, Tsvetnenko E, Total and differential hemocyte counts in western rock lobsters Panulirus cygnus George. under post-harvest stress. Freshwater Res. 1997;48:863-868.

49. Fotedar R. Nutrition of marron, Cherax tenuimannus (Smith) under different culture environments-a comparative study (Unpublished) PhD thesis. Perth, Western Australia: Curtin University of Technology, Australia, pp.1998;174.

50. Jussila J, Mannonen A. Marron (Cherax tenuimanus) and noble crayfish (Astacus astacus) hepatopancreas energy and its relationship to moisture content. Aquaculture. 1997;149(1-2):157-1561.

51. Jussila J. Physiological responses of astacid and parastacid crayfishes (Crustacea: Decapoda) to conditions of intensive culture. Department of Applied Zoology \& Veterinary Medicine. University of Kuopio, Finland. 1999.
52. Ambas I, Fotedar R, Buller N. Synbiotic effect of Bacillus mycoides and organic selenium on immunity and growth of marron, Cherax cainii (Austin, 2002). Aquaculture research. 2016;48(6):2729-2740.

53. Ambas I, Suriawan A, Fotedar R. Immunological responses of customised probiotics-fed marron, Cherax tenuimanus, (Smith 1912) when challenged with Vibrio mimicus. Fish \& shellfish immunol. 2013;35(2):262-270.

54. Ambas I, Fotedar R, Buller N. Bacillus mycoides Improves Health of Gastrointestinal Tract in Marron (Cherax cainii, Austin 2002). J Aquac Mar Biol. 2015 b ;2(2):1-7.

55. Ambas I, Fotedar R, Buller N. Survival and immunity of marron Cherax cainii (Austin, 2002) fed Bacillus mycoides supplemented diet under simulated transport. J Aquac Res Dev. 2015c;7:1-6.

56. Sakai M. Current research status of fish immunostimulants. Aquaculture. 1999;172(1-2):63-92.

57. Gomez GD, Balcazar JL. A review on the interactions between gut microbiota and innate immunity of fish. FEMS Immunol Med Microbiol. 2008;52(2):145-154.

58. Purivirojkul W, Maketon M, Areechon N. Probiotic Properties of Bacillus pumilus, Bacillus sphaericus and Bacillus subtilis in Black Tiger Shrimp (Penaeus monodon Fabricius) Culture. Kasetsart J (Nat. Sci.). 2005;39:262-273.

59. Yang HL, Sun YZ, Ma RL, et al. Probiotic Psychrobacter sp. improved the autochthonous microbial diversity along the gastrointestinal tract of grouper Epinephelus coioides. J Aquac Res Development. 2011.

60. Ringø E, Gatesoupe FJ. Lactic acid bacteria in fish: a review. Aquaculture. 1998;160(3-4):177-203.

61. Bairagi A, Ghosh KS, Sen SK, et al. Enzyme producing bacterial flora isolated from fish digestive tracts. Aquaculture International. 2002;10(2):109-121.

62. Wang YB, Li JR, Lin J. Probiotics in aquaculture: Challenges and outlook. Aquaculture. 2008;281(1-4):1-4.

63. Panigrahi A, Kiron V, Puangkaew J, et al. The viability of probiotic bacteria as a factor influencing the immune response in rainbow trout Oncorhynchus mykiss. Aquaculture. 2005;243(1-4):241-254.

64. Thompson J, Gregory S, Plummer S, et al. An in vitro and in vivo assessment of the potential of Vibrio spp. as probiotics for the Pacific White shrimp, Litopenaeus vannamei. J App Microbiology. 2010;109(4):1177-1187.

65. Iehata S, Inagaki $\mathrm{T}$, Okunishi $\mathrm{S}$, et al. Improved gut environment of abalone Haliotis gigantea through Pediococcus sp. Ab1 treatment. Aquaculture. 2010;305(1-4):59-65.

66. Nikoskelainen S, Nikoskelainen A, Ouwehand Gr, et al. Immune enhancement in rainbow trout (Oncorhynchus mykiss) by potential probiotic bacteria (Lactobacillus rham nosus). Fish \& shellfish immunology. 2003;15(5):443-452.

67. Tapia-Paniagua ST, Vidal S, Lobo C, et al. The treatment with the probiotic Shewanella putrefaciens Pdp11 of specimens of Solea senegalensis exposed to high stocking densities to enhance their resistance to disease. Fish \& shellfish immunology. 2014;41(2):209-221.

68. Johansson MW, Keyser P, Sritunyalucksana K, et al. Crustacean haemocytes and haematopoiesis. 2000;191(1-3):45-52.

69. Nugroho RA, Fotedar R. Comparing the effects of dietary selenium and mannan oligosaccharide supplementation on the growth, immune function, and antioxidant enzyme activity in the cultured marron Cherax cainii (Austin, 2002). Aquaculture int. 2013;22(2):585-596.

70. Hammer HS, Bishop CD, Watts SA. Activities of three digestive enzymes during development in the crayfish Procambarus clarkii (Decapoda). . Journal of the Crustacean Biology. 2000;20(4):614-620.

71. Lazado, Caipang CMA, Kiron V. Enzyme from the bacteria of Atlantic cod, Gadus morhua and their influence on intestinal enzyme activity. Aquaculture Nutrition. 2012;18(4):423-431. 